\title{
Hierarchical Contributions of Allorecognition Pathways in Chronic Lung Rejection
}

\author{
Worakij Chalermskulrat, Isabel P. Neuringer, W. June Brickey, Nathan J. Felix, Scott H. Randell, Jenny P. Ting, \\ and Robert M. Aris \\ Division of Pulmonary Disease and Critical Care Medicine and the Lung Transplantation Program; and Department of Microbiology and \\ Immunology, Lineberger Comprehensive Cancer Center, University of North Carolina, Chapel Hill, North Carolina
}

\begin{abstract}
The role of allorecognition in initiating lung graft rejection is not clearly defined. Using the heterotopic tracheal transplantation model, we examined the contributions of the indirect and direct allorecognition pathways in chronic airway rejection. Fully mismatched, wild-type grafts were transplanted into major histocompatibility complex $(\mathrm{MHC}) \mathrm{II}^{-/-}$, class II-like accessory molecule (H2$\mathrm{DM} \alpha)^{-1-}$ using $\mathrm{MHC} \mathrm{\textrm {I } ^ { - 1 - }}$ and wild-type allorecipients as control subjects. Similarly, $\mathrm{MHC} \mathrm{I}^{-/-}, \mathrm{MHC} \mathrm{II}^{-1-}$, or $\mathrm{MHC} \mathrm{I} / \mathrm{II}^{-/-}$allografts were transplanted into wild-type mice with appropriate control subjects. Grafts from nonimmunosuppressed recipients were evaluated at Weeks 2, 4, and 6. Grafts transplanted into $\mathrm{MHC} \mathrm{II}^{-/-}$and H2-DM $\alpha^{-1-}$ allorecipients showed a more intact epithelium and reduced lumen obliteration compared with grafts transplanted into wild-type or $\mathrm{MHC} \mathrm{I}^{-1-}$ allorecipients ( $p<0.05$ for each). These grafts exhibited abundant CD4+ and CD8 + cell infiltrates similar to control allografts. $\mathrm{MHC} \mathrm{I} \mathrm{I}^{-/-}$and $\mathrm{MHC} \mathrm{I} / \mathrm{II}^{-/-}$but not $\mathrm{MHC} \mathrm{II}^{-/-}$ allografts placed in wild-type animals demonstrated less severe rejection compared with allograft control subjects ( $p<0.05$ for each). Although the indirect allorecognition pathway has the strongest influence on rejection, the direct pathway is sufficient to ultimately cause chronic airway rejection. In addition, these results suggest that MHC class I molecules are the principal alloantigens in the mouse heterotopic tracheal model of obliterative bronchiolitis.
\end{abstract}

Keywords: allorecognition; alloantigen; lung transplant; trachea transplant model; obliterative bronchiolitis

Lung transplantation has become a successful clinical therapy for individuals with diverse end-stage pulmonary diseases. Despite advances in several aspects of pulmonary transplant medicine, chronic lung allograft rejection, manifested as progressive airway obstruction, namely obliterative bronchiolitis (OB), remains the leading cause of morbidity and mortality among long-term survivors of lung transplantation (1). The treatment of $\mathrm{OB}$ is ineffective, mainly because of our lack of knowledge of the pathogenesis of this disease. In the mouse heterotopic tracheal transplant model, allografts, but not isografts, develop a defined, predictable succession of airway inflammation, epithelial injury and denudation, and lumen fibroproliferation, resulting in airway obliteration replicating

(Received in original form September 25, 2002; accepted in final form November 20, 2002) Supported by a Cystic Fibrosis Foundation research grant (R.M.A. and W.C.), an American Lung Association research grant (I.P.N.), and National Institutes of Health grants HL67178 (I.P.N.), HL58345 (S.H.R.), Al29564 (J.P.T.), and DK38108 (J.P.T.). W.C. is the recipient of an American Lung Association Fellowship Award. This work was reported, in part, in the form of an abstract $(55,56)$ and was presented at the 96th and 98th American Thoracic Society International Conferences (May 8, 2000, in Toronto, Ontario, Canada, and May 20, 2002, in Atlanta, Georgia).

Correspondence and requests for reprints should be addressed to Robert M. Aris, M.D., 420 Burnett-Womack Building, CB\# 7020, Chapel Hill, NC 27599. E-mail: aris@med. unc.edu

Am J Respir Crit Care Med Vol 167. pp 999-1007, 2003

Originally Published in Press as DOI: 10.1164/rccm.200209-10990C on November 21, 2002

Internet address: www.atsjournals.org the pathology of human OB (2). Studies have validated the use of the mouse heterotopic tracheal transplant model and yielded important initial observations showing that alloimmune injury that leads to OB (3-8).

The initial and central event that ultimately leads to graft rejection is allorecognition. Allospecific T cells may be activated by two distinct pathways (9-13). The direct pathway is defined by the allorestricted activation of recipient $\mathrm{T}$ cells by donor antigen-presenting cells, whereas the indirect pathway refers to activation of recipient $T$ cells through the interaction with preprocessed allopeptides presented by recipient antigen-presenting cells in a self major histocompatibility complex (MHC) II-restricted manner. Although the mechanism for indirect allorecognition is similar to the physiologic mechanism of host defense, the mechanism of direct allorecognition pathway is less well characterized. Overall, the relative contributions of the indirect and direct allorecognition pathways to organ graft rejection remain largely unknown and have not been well studied in the tracheal transplant model.

Genetically engineered mice have been generated and used to examine the biologic function of components of the antigen processing pathway. The MHC class II molecules are heterodimers consisting of $\alpha$ and $\beta$ chains, which are assembled in the endoplasmic reticulum, associated with the invariant chain and transported into the endosomal compartment where the invariant chain is proteolytically degraded into class II-associated invariant chain peptide (CLIP). The class II-like accessory molecule HLA-DM or its murine equivalent, H2-DM, catalyzes the dissociation of CLIP and assists in the loading of the antigenic peptides, thereby playing an important role in the orderly trafficking of MHC IIpeptide complexes to the cell surface. Mice deficient in $\mathrm{MHC}$ class II expression have been generated by deleting the $\mathrm{A}_{\beta}$ gene, resulting in undetectable MHC class II expression (14, 15). Mice deficient in MHC class I expression have also been generated by disruption of the gene encoding the $\beta 2$-microglobulin, a polypeptide required for proper assembly and cell surface expression of MHC class I molecules $(16,17)$. In addition, mice deficient in H2-DM have been generated by disruption of the $\mathrm{H} 2-\mathrm{DM} \alpha$ gene, which encodes the $\alpha$ subunit for H2-DM. In the absence of H2-DM $\alpha$, CLIP cannot be dissociated from and exogenous antigens cannot be complexed with newly synthesized MHC class II molecules (1821). H2-DM $\alpha$ deficiency on the C57BL/6 background results in an almost complete blockade of alloantigen processing and presentation by MHC class II molecules (21-23).

Previous studies using MHC II-deficient (skin) allografts (i.e., absence of donor MHC II-bearing antigen-presenting cells) to eliminate the direct allorecognition pathway have concluded that indirect allorecognition is sufficient to cause rejection $(24,25)$. However, recent studies have indicated that allograft antigen-presenting cell cells can directly activate $\mathrm{CD} 8+\mathrm{T}$ cells through $\mathrm{MHC}$ class I molecules and in 
the absence of CD4+ T cell "help" (26-28), resulting in rejection $(26,27)$. Therefore, the use of MHC II-deficient grafts cannot entirely exclude direct (MHC I-dependent) allorecognition $(24,25)$. In the experiments described herein, we pursued an alternative and comprehensive approach to evaluate the role and contribution of each allorecognition pathway and donor MHC molecules in lung transplant rejection. First, we transplanted wild-type tracheal allografts into MHC II ${ }^{-/-}$or H2-DM $\alpha^{-l-}$ mice, which have different disruptions in the class II-dependent antigen presentation process that, in effect, eliminates indirect allorecognition. Second, we transplanted MHC I-, II-, and I/II-deficient allografts into wild-type recipients to assess the role of MHC I and MHC II-mediated direct allorecognition and MHC molecules as alloantigens.

\section{METHODS}

\section{Mice and Study Design}

The following female mice between 8 and 12 weeks of age were used: wild-type BALB/c $\left(\mathrm{H}^{\mathrm{d}}\right)$ and $\mathrm{C} 57 \mathrm{BL} / 6\left(\mathrm{H}^{\mathrm{b}}\right)$ (Harlan Labs, Indianapolis, IN), $\mathrm{H} 2^{\mathrm{b}}$ MHC class I deficient ( $\left.\mathrm{MHC} \mathrm{I}^{-1-}\right)(17), \mathrm{H} 2^{\mathrm{b}}$ MHC class II deficient (MHC $\left.\mathrm{II}^{--}\right)$(14), and $\mathrm{H} 2^{\mathrm{b}}$ MHC class I and II deficient (MHC I/II ${ }^{-l-}$ ) (29) (Taconic Labs, Germantown, NY). In addition, H2$\mathrm{DM} \alpha^{-1-}$ mice were backcrossed onto the $\mathrm{H} 2^{\mathrm{b}}$ background for nine generations and were bred and maintained at the University of North Carolina at Chapel Hill (UNC) (18). First, allografts from wild-type
$\mathrm{H} 2^{\mathrm{d}}$ mice were transplanted into fully mismatched $\mathrm{MHC} \mathrm{I}^{-/-}$, MHC $\mathrm{II}^{-/-}, \mathrm{H} 2-\mathrm{DM} \alpha^{-/-}$, and wild-type $\mathrm{H} 2^{\mathrm{b}}$ mice. For isograft control subjects, tracheae from wild-type $\mathrm{H} 2^{\mathrm{b}}$ were transplanted into wild-type $\mathrm{H} 2^{\mathrm{b}}$ mice. Second, tracheal grafts were obtained from $\mathrm{MHC} \mathrm{I}^{-/-}$, $\mathrm{MHC} \mathrm{II}^{-1-}$, MHC I/II ${ }^{-1-}$, and wild-type $\mathrm{H} 2^{\mathrm{b}}$ or $\mathrm{H} 2^{\mathrm{d}}$ mice and placed into wild-type $\mathrm{H} 2^{\mathrm{d}}$ mice. All mice were maintained following the National Institutes of Health guidelines for the care and use of laboratory animals under specific pathogen-free conditions.

\section{Mouse Heterotopic Tracheal Transplantation}

As previously described (4-6), tracheae were transplanted into a subcutaneous pocket behind the neck of the recipient after anesthesia was achieved by injecting Domitor $(5 \mathrm{mg} / \mathrm{kg}) / \mathrm{Ketamine}(100 \mathrm{mg} / \mathrm{kg})$ (Division of Laboratory Animal Medicine, UNC) intraperitoneally and then reversed with Antisedan $(2.5 \mathrm{mg} / \mathrm{kg}$ ) (Division of Laboratory Animal Medicine), introduced subcutaneously. No immunosuppressant was used.

\section{Morphometry}

Grafts were harvested at Weeks 2, 4, and 6. Tissue processing, staining, and image acquisition have been previously described (4-6). Detachment of the differentiated (ciliated) epithelium (epithelial injury) and lumen obliteration (fibroproliferation) were examined to determine airway rejection. The intact differentiated epithelium and total airway circumference were measured at the level of the sub-basement membrane. Quantitation of the epithelialization and fibroproliferation was performed using the Metamorph Image analysis program (West Chester, PA) by three independent, blinded reviewers and was expressed

\section{2 wk (40x)}

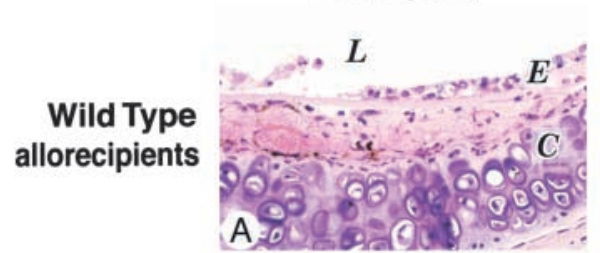

Isorecipients

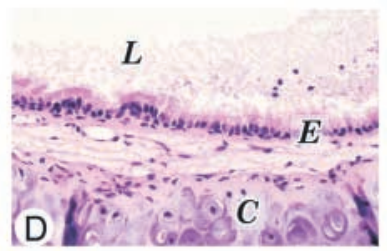

MHC II-(-/)
allorecipients

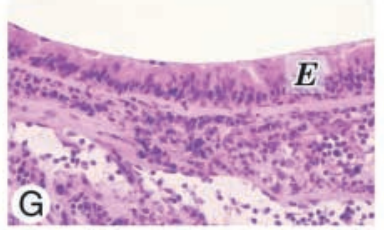

H2-DM $\alpha^{(-/-)}$

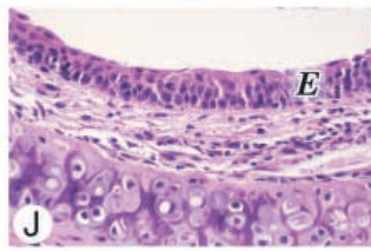

2 wk (10x)
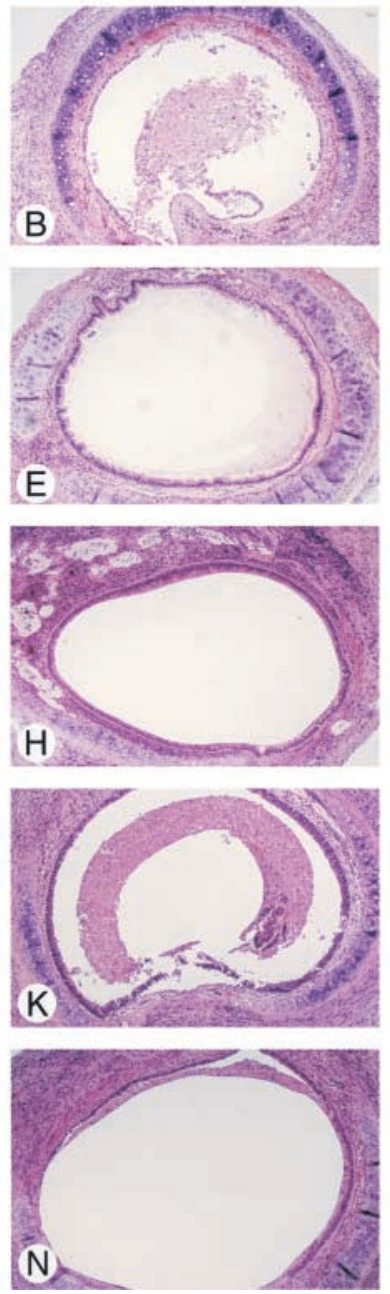

4 wk (10x)
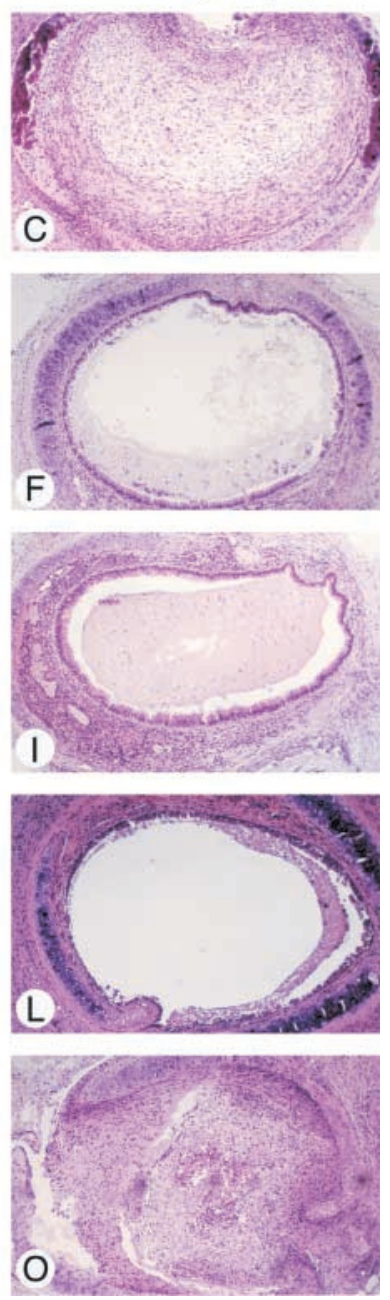

Figure 1. Histopathology of wildtype $\mathrm{H}^{\mathrm{d}}$ tracheal grafts transplanted into wild-type, $\mathrm{MHC}$-, or $\mathrm{H} 2$-DM $\alpha$-deficient $\mathrm{H} 2^{\mathrm{b}}$ allorecipients at Weeks $2(10 \times$ and $40 \times$ ) and $4(10 \times)$ (hematoxylin and eosin). Tracheal grafts transplanted into wild-type allorecipients $(A-C)$, but not wild-type isorecipients $(D-F)$, showed a successive loss of intact, ciliated epithelium, and diminished lumen patency, eventuating in complete airway obliteration by Week 4 . Grafts transplanted into $\mathrm{MHC}$ $\mathrm{II}^{-/-}(\mathrm{G}-\mathrm{I})$ and $\mathrm{H} 2-\mathrm{DM} \alpha^{-1-}(J-L)$, but not $\mathrm{MHCl}^{-1-}(\mathrm{M}-\mathrm{O})$, showed significantly less severe chronic airway rejection. $\mathrm{E}=$ epithelium, $\mathrm{L}=$ airway lumen, $\mathrm{C}=$ tracheal cartilage. 
as the fraction of total airway circumference or of the total lumen crosssectional area, respectively (4-6).

\section{Immunohistochemistry}

Frozen sections were air dried, fixed in chilled acetone, and blocked with 5\% normal goat serum (Jackson ImmunoResearch, West Grove, PA) and avidin-biotin block (Vector Labs, Burlingame, CA). The sections were incubated with monoclonal rat anti-mouse CD4+ or CD8+ antibodies, then biotinylated goat anti-rat antibody, and finally streptavidin-horseradish-peroxidase (Pharmingen, San Diego, CA). Optimal dilutions and incubation periods were determined empirically. Duplicate sections on the same slide were incubated with rat IgG2a (Jackson ImmunoResearch) as a negative isotype control. The diaminobenzidine substrate (Sigma, St. Louis, MO) was used, and sections were counterstained with Light Green (Fisher Scientific Co., Pittsburgh, PA). Cells were counted within the area outlined by an equidistant line, $10 \mu \mathrm{m}$ outward from the sub-basement membrane. In accordance with the previously described profile of immune cellular infiltration into allografts in this model (4), grafts were examined for CD4+ and CD8+ T cells at Week 2.

\section{Statistical Analysis}

Analyses were performed using SigmaStat software (SPSS Inc., Chicago, IL). Parameters were compared at each time point using the student's $t$-test. A two-tailed $\alpha$ level of $\mathrm{p}<0.05$ was considered significant. Repeated-measures analyses of variance were used (8) to confirm the results from the $t$-test analyses.

\section{RESULTS}

\section{Allogeneic Transplantation into Fully Mismatched, Wild-type $\mathrm{H} 2^{\mathrm{b}}$ or $\mathrm{H} 2^{\mathrm{d}}$ Mice}

The wild-type $\mathrm{H} 2^{\mathrm{d}}$ and $\mathrm{H} 2^{\mathrm{b}}$ tracheal isografts showed a complete, intact, fully differentiated epithelium and patent lumen at 2, 4, and 6 weeks $(\mathrm{n}=4$, at each time point for both arms; Figures 1 and 2). Therefore, the initial ischemic insult by itself had no impact on the subsequent repair of the epithelium or the OB in this transplant model.

At 2, 4 and 6 weeks, the allografts (wild-type $\mathrm{H} 2^{\mathrm{d}}$ grafts transplanted into fully mismatched, wild-type $\mathrm{H} 2^{\mathrm{b}}$ recipients, $\mathrm{n}=$ 3 to 4 , at each time point) had less intact, fully differentiated (ciliated) epithelium compared with the isografts (wild-type $\mathrm{H} 2^{\mathrm{b}}$ grafts transplanted into wild-type isorecipients, $n=4$, at each time point $)(\mathrm{p}=0.03, \mathrm{p}<0.001$, and $\mathrm{p}<0.001$, respectively; Figures 1 and 2A). After epithelial denudation, the lumen of the allografts displayed markedly decreased patency compared with the isografts $(n=3, p=0.002$ at 4 weeks, and $n=4, p<$ 0.001 at 6 weeks; Figures 1 and 2B).

Similar results were seen in wild-type $\mathrm{H} 2^{\mathrm{b}}$ allografts transplanted into wild-type $\mathrm{H} 2^{\mathrm{d}}$ recipients as compared with $\mathrm{H} 2^{\mathrm{d}}$ allografts transplanted into wild-type $\mathrm{H} 2^{\mathrm{b}}$ recipients $(\mathrm{n}=3$ to 5 , each arm and time point; $p \leqslant 0.005$ for ciliated epithelium at 2,4 , and 6 weeks and $p<0.005$ for lumen patency at 4 or 6 weeks; Figures 5, 6A, and 6B), which reproduced the results from previous studies (3-8). Therefore, we demonstrated a uniform profile of airway rejection across two strains of mouse recipients.

\section{Testing the Indirect Pathway of Allorecognition}

Allogeneic transplantation into fully mismatched, MHC II-deficient mice. At 2 weeks, wild-type grafts transplanted into fully mismatched $\mathrm{MHC} \mathrm{II}{ }^{-1-}$ allorecipients $(\mathrm{n}=4)$ had more intact, ciliated epithelium than those transplanted into wild-type allorecipients $(p=0.01)$. There was no lumen obliteration observed in any of the grafts (Figures 1,2A, and 2B). At 4 weeks, wildtype grafts transplanted into fully mismatched $\mathrm{MHC} \mathrm{II}^{-1-}$ allorecipients $(n=4)$ had significantly more intact ciliated epithelium $(p=0.04)$ and more airway lumen patency $(p=0.005)$ than wild-type grafts transplanted into wild-type allorecipients. At 6
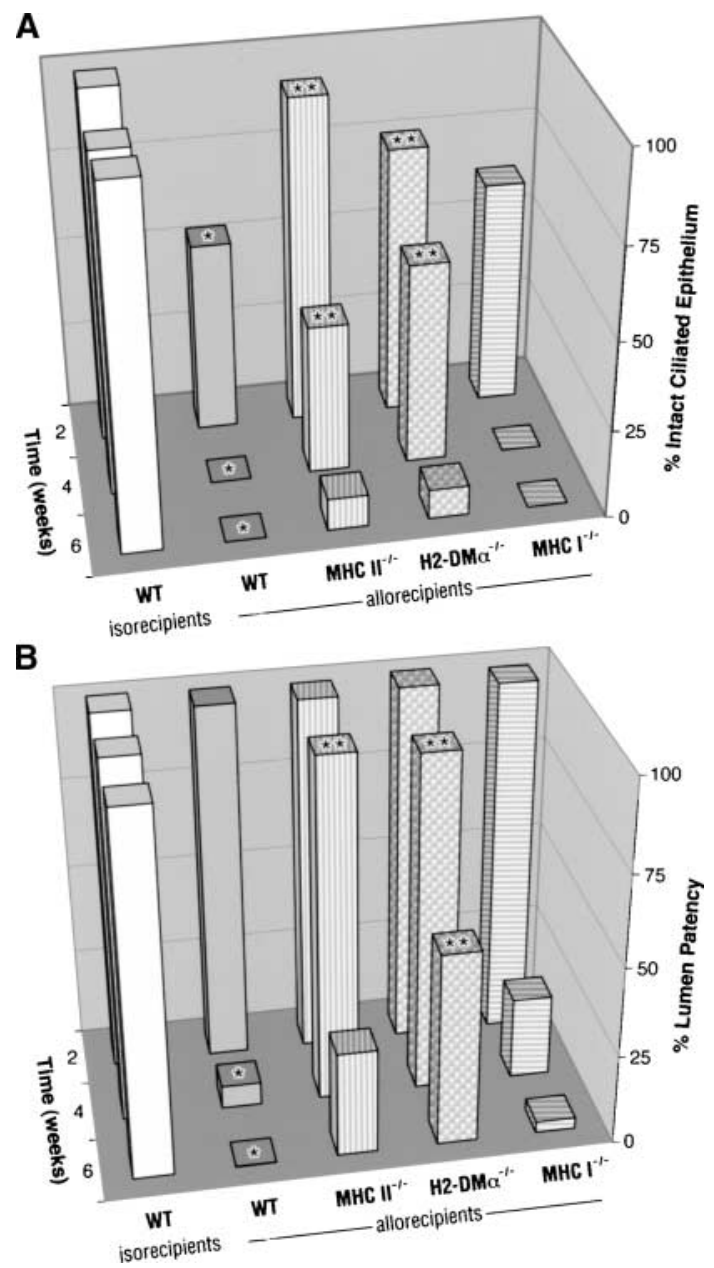

Figure 2. Airway rejection in wild-type (WT) grafts transplanted into wild-type, MHC-, or $\mathrm{H} 2-\mathrm{DM} \alpha$-deficient recipients is shown as $(A)$ the mean percentage of intact ciliated airway epithelium and $(B)$ the mean percentage of airway lumen patency. ${ }^{*}$ Comparisons $(p<0.05)$ between the control allografts and the control isografts at the same time point. ${ }^{* *}$ Comparisons $(p<0.05)$ between the experimental arms and the control allografts placed in wild-type recipients at the same time point. Grafts transplanted into MHC II- and H2-DM $\alpha$-deficient allorecipients, but not grafts transplanted into $\mathrm{MHC} \mathrm{I-deficient} \mathrm{allorecipients,} \mathrm{showed}$ significantly less epithelial denudation and airway obliteration from 2 to 6 weeks when compared with grafts transplanted into wild-type recipients.

weeks, wild-type grafts transplanted into fully mismatched MHC $\mathrm{II}^{-1-}$ allorecipients $(\mathrm{n}=3)$ underwent epithelial denudation and lumen obliteration similar to wild-type grafts transplanted into wild-type allorecipients ( $\mathrm{p} \geqslant 0.2$ each; Figures $1,2 \mathrm{~A}$, and $2 \mathrm{~B}$ ).

Allogeneic transplantation into fully mismatched, H2-DMadeficient mice. At 2 weeks, wild-type grafts transplanted into $\mathrm{H} 2-\mathrm{DM} \alpha^{-1-}$ allorecipients $(\mathrm{n}=6)$ had more intact ciliated epithelium than those transplanted into wild-type allorecipients $(\mathrm{p}=0.007)$. There was no lumen obliteration (Figures 1, 2A, and $2 \mathrm{~B}$ ). At 4 weeks, wild-type grafts transplanted $\mathrm{H} 2-\mathrm{DM} \alpha^{-1-}$ allorecipients $(n=6)$ showed significantly more intact, ciliated epithelium $(\mathrm{p}=0.005)$ and more airway lumen patency $(\mathrm{p}=$ 0.001 ) than grafts transplanted into wild-type allorecipients. At 6 weeks, wild-type grafts transplanted into $\mathrm{H} 2-\mathrm{DM} \alpha^{-/-}$allorecipients $(n=4)$ showed epithelial loss similar to wild-type transplanted into wild-type allorecipients $(p \geqslant 0.2$; Figure $2 \mathrm{~A})$; however, they showed significantly less lumen obliteration $(\mathrm{p}=0.05$; Figures 1, 2A, and 2B). 
CD4+

\section{Wild Type allorecipients}

Isorecipients

\section{MHC II $(--)$ allorecipients}
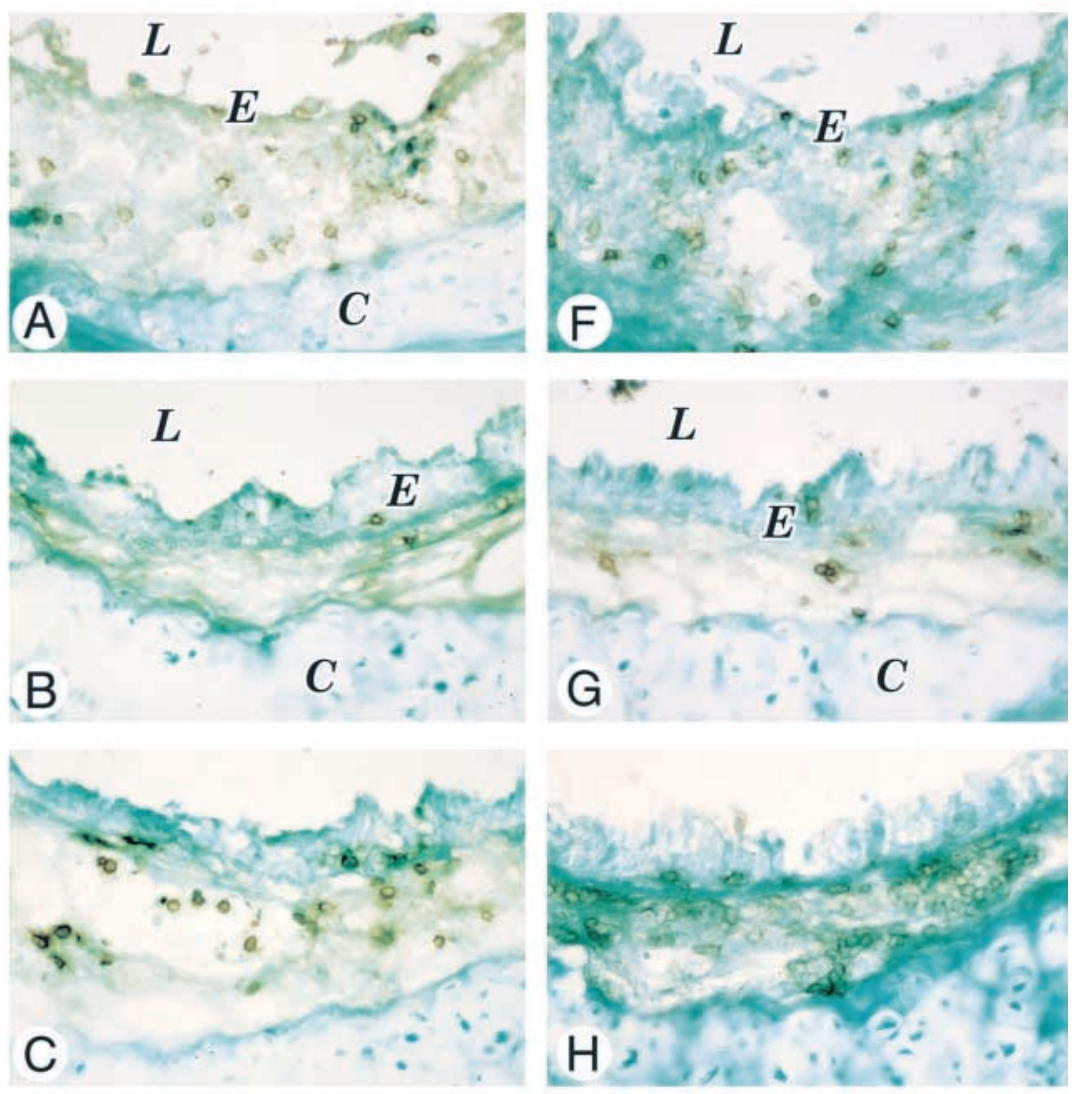

Figure 3. Immunohistochemical staining for $\mathrm{CD} 4+(A-E)$ and $\mathrm{CD} 8+(F-J)$ cells in wild-type tracheal grafts transplanted into MHC- or H2-DM $\alpha$-deficient allorecipients at 2 weeks. Magnification $\times 40 . \mathrm{E}=$ epithelium, $\mathrm{L}=$ airway lumen, $C=$ tracheal cartilage.
.

\section{H2-DM $\alpha^{(--)}$ allorecipients}
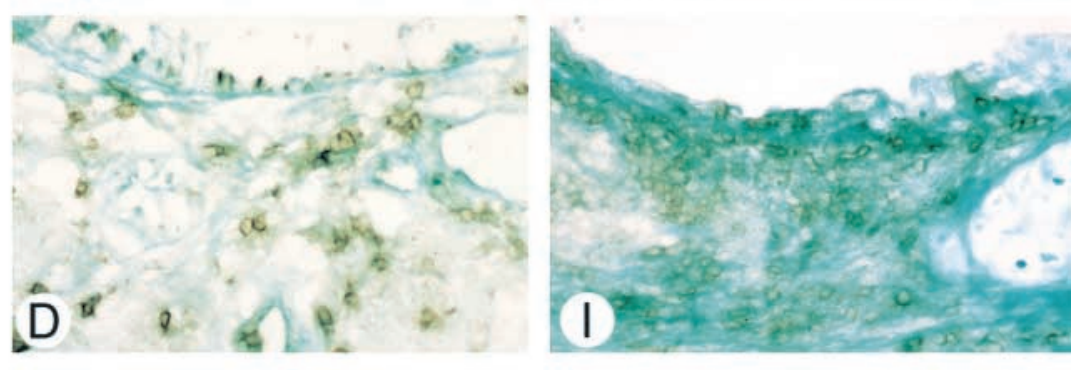

\section{$\mathrm{MHCI}^{(--)}$ allorecipients}

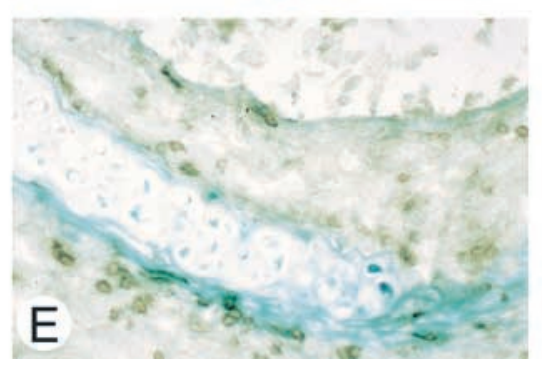

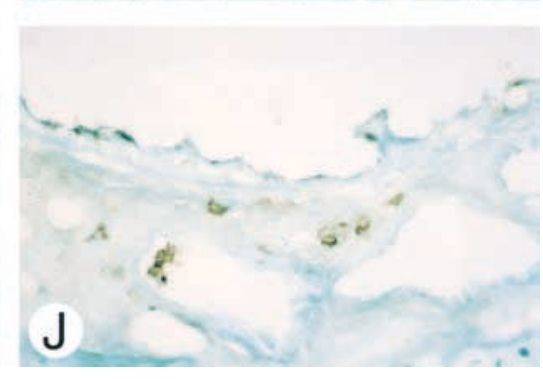


A

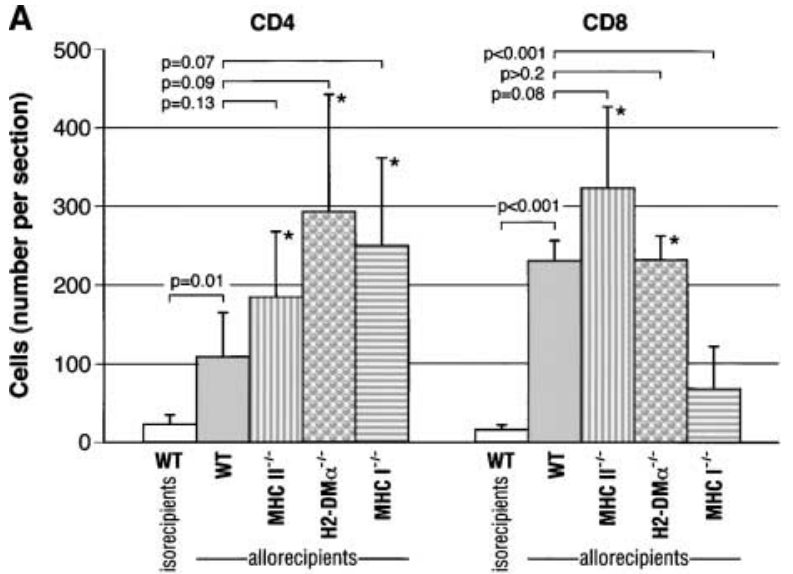

B

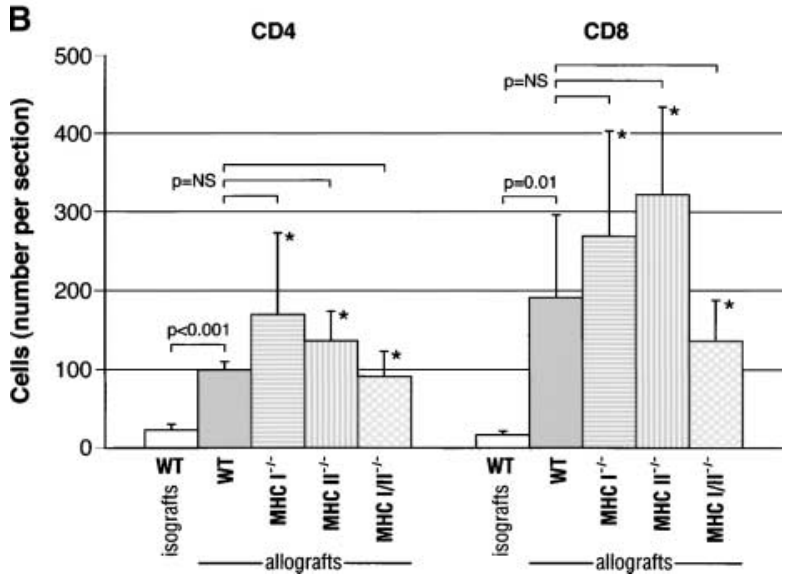

Figure 4. The mean number ( \pm SD) of graft-infiltrating $\mathrm{CD} 4+$ and CD8 + lymphocytes: $(A)$ wild-type grafts transplanted into MHC- or $\mathrm{H} 2-\mathrm{DM} \alpha$-deficient allorecipients. $\mathrm{H} 2-\mathrm{DM}^{-1-}$ and $\mathrm{MHC} \mathrm{II}^{-1-}$ mice showed similar numbers of allograft-infiltrating CD4+ and CD8+ lymphocytes in comparison to the control allografts ( $p>0.05$, each). A lower mean CD8 + cell count was observed in wild-type grafts transplanted into $\mathrm{MHC} \mathrm{I}^{-1-}$ mice $(\mathrm{p}<0.01)$. (B) MHC-deficient allografts transplanted into wild-type allorecipients. $\mathrm{MHC} \mathrm{I}^{-/-}, \mathrm{II}^{-/-}$, and $\mathrm{I} / \mathrm{II}^{-/-}$ allografts showed trends toward higher numbers of CD4+ and CD8+ infiltrating cells when compared with the control allografts $(p>0.05$, each). Bracketed $p$ values show comparisons between the experimental arms or the control isografts with the control allografts. *Comparisons $(p<0.05)$ between the experimental arms and the control isografts. $\mathrm{WT}=$ wild type.

into wild-type allorecipients ( $\mathrm{p}=0.08$ and $\mathrm{p}>0.2$, respectively). A lower mean CD8 + cell count was observed in wild-type grafts transplanted into $\mathrm{MHC} \mathrm{I}^{-1-}$ mice $(\mathrm{p}<0.001$; Figures 3 and $4 \mathrm{~A})$.

\section{Testing the Direct Pathway of Allorecognition and the Role} of Donor MHC Molecules

Transplantation of $\mathrm{MHC} \mathrm{II}^{-/-}$tracheal allografts into fully mismatched, wild-type mice. At each time point ( $\mathrm{n}=5$ for each), the $\mathrm{MHC} \mathrm{II}^{-1-}$ allografts had a similar amount of ciliated epithelium and lumen obliteration as the wild-type allografts $(p>0.2$ for ciliated epithelium or lumen obliteration at each time point; Figures 5, 6A, and 6B).

Transplantation of $\mathrm{MHC} \mathrm{I}^{-/-}$tracheal allografts into fully mismatched, wild-type mice. At 2 weeks, $\mathrm{MHC} \mathrm{I}^{-/-}$allografts $(\mathrm{n}=$ 5) had more ciliated epithelium than wild-type allografts ( $\mathrm{p}=$ $0.05)$ and no lumen obliteration. At 4 weeks, these grafts $(n=7)$ showed more intact ciliated epithelium and less lumen oblitera- tion compared with wild-type allografts $(\mathrm{p}=0.05$ and $\mathrm{p}=0.004$, respectively). By 6 weeks, MHC I $^{-1-}$ allografts $(\mathrm{n}=5)$ developed lumen obliteration similar to wild-type allografts $(n=4, p>$ 0.2 for each; Figures 5, 6A, and 6B).

Transplantation of $M H C I / I I^{-1-}$ tracheal allografts into fully mismatched, wild-type mice. At 2 weeks, $\mathrm{MHC} \mathrm{I/ \textrm {II } ^ { - 1 - }}$ allografts $(\mathrm{n}=4)$ had more intact ciliated epithelium than wild-type allografts $(\mathrm{p}=0.05)$ and did not develop lumen obliteration. At Week 4, MHC I/II ${ }^{-/-}$allografts $(\mathrm{n}=6)$ had more intact ciliated epithelium and less lumen obliteration compared with wild-type allografts $(p=0.04$ and $p=0.006$, respectively). At Week 6 , although MHC I/II ${ }^{-/-}$allografts $(\mathrm{n}=6)$ lost their intact ciliated epithelium resembling wild-type allografts $(p>0.2)$, they showed significantly less airway lumen obliteration compared with wild-type $(\mathrm{p}=0.04)$, $\mathrm{MHC} \mathrm{I}^{-/-}(\mathrm{p}=0.04)$, or $\mathrm{MHC} \mathrm{II}^{-/-}$ $(\mathrm{p}=0.05)$ allografts (Figures 5, 6A, and 6B).

Graft-infiltrating lymphocytes in $\mathrm{MHC}$-deficient allografts. Wild-type allografts transplanted into wild-type $\mathrm{H}^{\mathrm{d}}$ mice $(\mathrm{n}=$ 5) showed an abundance of CD4+ and CD8+ cells compared with isografts $(99 \pm 10.4$ versus $23 \pm 7.5, \mathrm{p}<0.001$, and $191 \pm$ 104.5 versus $16 \pm 5.1, \mathrm{p}=0.01$, respectively; Figure 4B). MHC $\mathrm{I}^{-/-}, \mathrm{II}^{-1-}$, and $\mathrm{I} / \mathrm{II}^{-1-}$ allografts placed in wild-type mice had a trend toward higher CD4+ $(\mathrm{p}=0.14, \mathrm{p}=0.07$, and $\mathrm{p}>0.2$, respectively) and $\mathrm{CD} 8+(\mathrm{p}=0.17, \mathrm{p}=0.06$, and $\mathrm{p}=0.17$, respectively) cells when compared with wild-type allografts (Figure 4B).

\section{DISCUSSION}

In this study, we report on the hierarchical importance of the indirect alloantigen recognition pathway over the direct pathway in the mouse model of chronic airway rejection. First, in the presence of the direct allorecognition pathway, we showed that the disruption of the indirect allorecognition pathway using $\mathrm{MHC} \mathrm{II}^{-1-}$ or $\mathrm{H} 2-\mathrm{DM} \alpha^{-/-}$recipient mice, which lack cell surface MHC II molecules or have disrupted loading of peptide antigens, respectively, led to less chronic airway rejection. Because equal or greater numbers of allograft-infiltrating CD4+ and CD8+ T lymphocytes were found in wild-type allografts transplanted into $\mathrm{H} 2-\mathrm{DM} \alpha^{-1-}$, and to our surprise, $\mathrm{MHC} \mathrm{II}^{-1-}$ recipients (compared with wild-type control allografts), the attenuation of rejection was not due to the inability of the recipient's T lymphocytes to access these grafts. Second, in the presence of the indirect pathway, $\mathrm{MHC} \mathrm{II}^{-/-}$allografts (and passenger leukocytes), which lack the exogenous (MHC II-mediated) direct allorecognition pathway, developed chronic rejection in the same manner as control allografts. Third, because MHC I- and MHC I/IIdeficient allografts placed into wild-type animals showed diminished rejection, MHC I peptides are important alloantigens in this model of chronic lung rejection. Endogenous (MHC I-mediated) direct allorecognition was not directly tested in this model but, if present, is a less important pathway based on the finding that wild-type grafts are rejected more slowly in recipients who have impaired indirect allorecognition (but intact MHC I direct allorecognition). Finally, the fact that $\mathrm{MHC} \mathrm{I/ \textrm {II } ^ { - 1 - }}$ grafts were eventually rejected suggested that non-MHC antigens (e.g., minor histocompatibility antigens) were sufficient to cause chronic rejection through the indirect pathway in this model.

The absence of indirect allorecognition pathway did not lead to indefinite survival of fully MHC-mismatched airway allografts as grafts placed into $\mathrm{MHC} \mathrm{II}^{-1-}$ and $\mathrm{H} 2-\mathrm{DM} \alpha^{-1-}$ mice but displayed a 2-week delay in epithelial denudation and lumen obliteration (Figure 2). This observation maybe explained by the fact that the direct allorecognition pathway, which triggers a less robust alloimmune response, was sufficient to result in complete airway allograft rejection at a slower pace. In addition, the equal 
2 wk (40x)

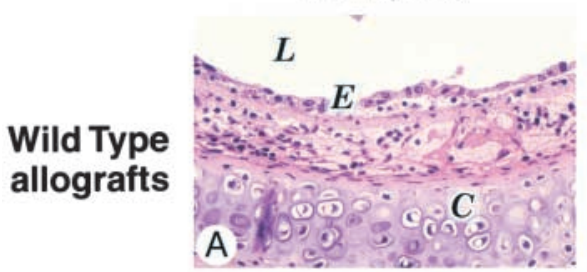

\section{$L$}

Isografts

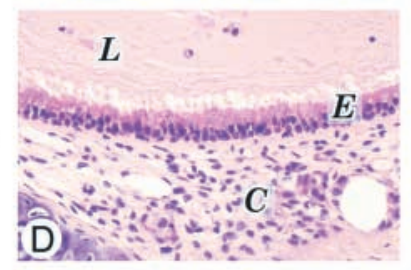

\section{MHC I I--) allografts}

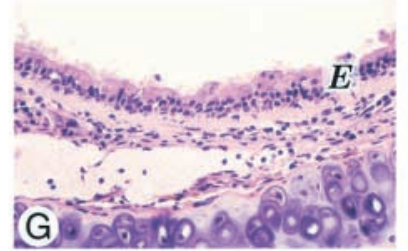

\section{MHC $\|^{(-/)}$ allografts}

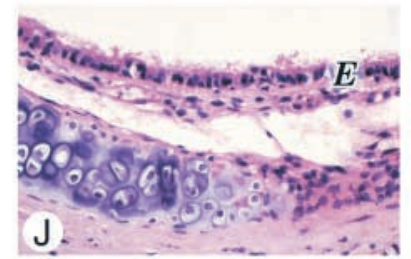

\section{MHC I/II ${ }^{(-/)}$ allografts}
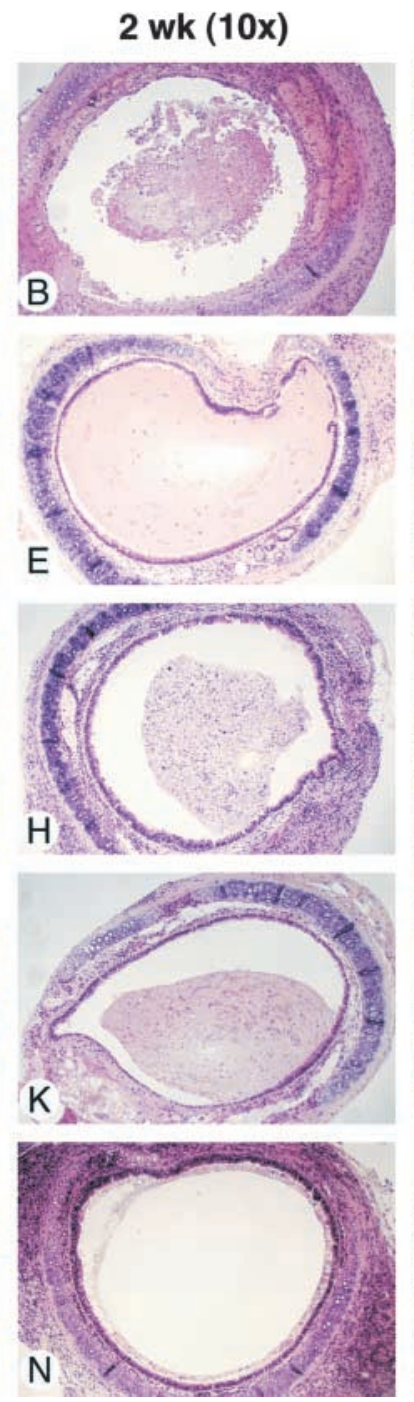

4 wk (10x)
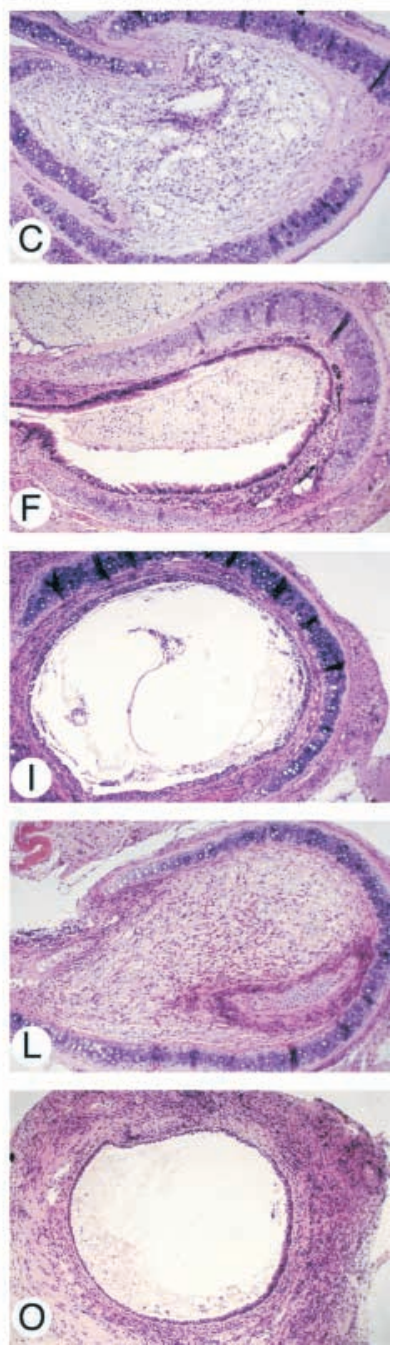

Figure 5. Histopathology of wild-type, MHC-deficient $\mathrm{H} 2^{\mathrm{b}}$ tracheal allografts transplanted into wild-type $\mathrm{H} 2^{\mathrm{d}}$ recipients at Weeks $2(\times 10$ and $\times 40)$ and 4 $(\times 10)$ (hematoxylin and eo$\sin )$. An identical profile of airway rejection was observed in wild-type $\mathrm{H} 2^{\mathrm{b}}$ allografts transplanted into wild-type $\mathrm{H} 2^{\mathrm{d}}$ recipients $(A-C)$ in comparison with that in wild-type $\mathrm{H}^{\mathrm{d}}$ allografts transplanted into wildtype $\mathrm{H} 2^{\mathrm{b}}$ recipients (Figures $1 \mathrm{~A}-1 \mathrm{C}) . \mathrm{MHCl}(\mathrm{G}-\mathrm{l})$ and $\mathrm{I} / \mathrm{II}^{-/-}$ $(M-O)$ but not $\mathrm{MHC} \mathrm{II}^{-1-}(J-L)$ allografts showed significantly less severe chronic airway rejection. $\mathrm{E}=$ epithelium, $\mathrm{L}=$ airway lumen, $\mathrm{C}=$ tracheal cartilage. or greater numbers of infiltrating lymphocytes in these grafts compared with wild-type allografts may signify weaker donor specificities, a characteristic of direct allorecognition (30). Alternatively, cross-presentation of antigens (occurring with MHC $\mathrm{II}^{-/-}$and $\mathrm{H} 2-\mathrm{DM} \alpha^{-/-}$antigen-presenting cells to recipient CD8+ T cells via MHC I molecules) may be responsible for this late rejection. However, this form of indirect allorecognition is almost certainly inconsequential in our experiments, as fully MHC-mismatched grafts were used. Therefore, recipient CD8+ $\mathrm{T}$ cells sensitized by allopeptides in the context of recipient $\mathrm{MHC}$ I molecules will not find such determinants on the donor grafts.

MHC II ${ }^{-1-}$ mice, due to deficient thymic selection of CD4+ T cells during embryonic development, have limited T-cell repertoires and very low numbers of resting and stimulated CD4+ lymphocytes $(14,15)$. In these mice, deficient T-cell populations, rather than abnormal antigen processing, might have attenuated the rejection process that we and others $(14,15)$ have observed. In contrast, $\mathrm{H} 2-\mathrm{DM} \alpha^{-1-}$ mice have slightly reduced numbers of CD4+ lymphocytes in the lymph nodes and spleens, but express a very diverse $\mathrm{T}$ cell receptor repertoire, quite similar to that of wild-type animals $(18-21,31,32)$. In addition, $\mathrm{H} 2-\mathrm{DM} \alpha^{-/-} \mathrm{CD} 4+$ lymphocytes display an allogeneic proliferative response (18-21, 31,33 ) and cytokine production (33) not different from wildtype mice. Therefore, the result of $\mathrm{H} 2-\mathrm{DM} \alpha^{-/-}$mice rejecting allografts in a pattern similar to $\mathrm{MHC} \mathrm{II}^{-1-}$ mice confirms the importance of the indirect allorecognition and antigenic peptide loading processes in mediating airway allograft rejection. Our results are also consistent with human studies, which have reported indirect evidence for the importance of the indirect allorecognition in OB (34-37) and with animal models (38-40) and human studies $(41,42)$ showing the importance of the indirect pathway in other organ transplants. In addition, our findings help explain the previous contradictory results showing that either the direct (43) or indirect (44) pathway may cause chronic airway rejection in the murine tracheal transplant model by demonstrating that each pathway contributes in a different way.

Previous studies, using MHC-deficient grafts, have demonstrated the importance of MHC I molecules in pancreatic transplantation $(45,46)$, MHC II molecules in heart transplantation (47), and both MHC I and II molecules in skin transplantation $(24,29)$. Although the MHC molecules expressed on the graft may function as alloantigens, they may also participate in the direct allorecognition pathway as antigen-presenting molecules. Therefore, efforts to understand the importance of MHC alloantigens in previous studies using $\mathrm{MHC}^{-/-}$grafts only (and not using $\mathrm{MHC}^{-/-}$hosts) may have been confounded by the variable importance of direct allorecognition among different organ transplants and vice versa $(24,25)$. By using MHC-deficient mice as 
A

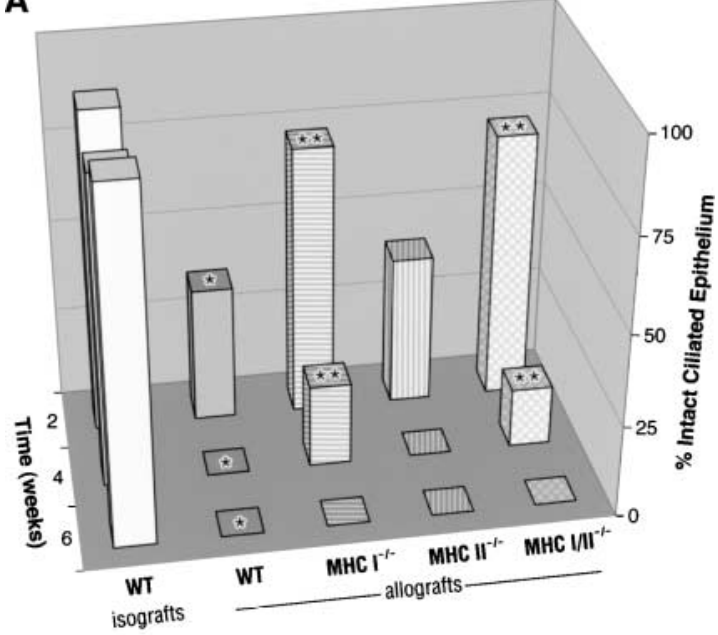

B

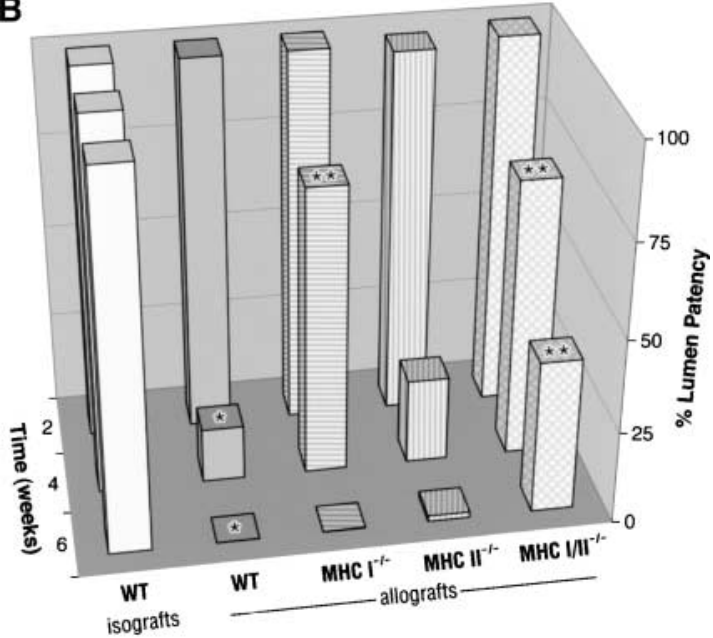

Figure 6. Airway rejection in wild-type (WT), MHC-deficient tracheal allografts transplanted into wild-type allorecipients, shown as $(A)$ the mean percentage of intact ciliated airway epithelium and $(B)$ the mean percentage of airway lumen patency. ${ }^{*}$ Comparisons $(p<0.05)$ between the control allografts and the control isografts at the same time point. ${ }^{* *}$ Comparisons $(p<0.05)$ between the experimental arms and the control allografts at the same time point. MHC I- and I/II-deficient allografts, but not MHC II-deficient allografts, showed significantly less epithelial denudation and airway obliteration from 2 to 6 weeks when compared with wild-type allografts.

both donors and recipients in separate experiments, our study design is unique in its ability to assess the role of MHC molecules both as antigen-presenting molecules and as alloantigens. This has allowed us to demonstrate unquestionably that MHC I peptides are important alloantigens in this model of chronic lung rejection. This finding is consistent with clinical studies in lung transplant recipients that mismatches at HLA class I increase the risk and severity of chronic lung rejection (48-51). Taken together, these observations suggest that matching donor and recipient HLA may reduce chronic lung rejection clinically.

Some limitations are worthy of note in this study. First, although the heterotopic mouse airway model has been successfully employed to study the pathogenesis of OB $(2-8,43,44)$, it does not perfectly replicate human $\mathrm{OB}$ due to the heterotopic position of the graft and the rapid course of rejection. Second, in $\mathrm{MHC} \mathrm{I}^{-/-}$mice, low levels of MHC I heavy chains may reach the cell surface and may play a role in rejection in both the
$\mathrm{MHC} \mathrm{I}^{-/-}$and MHC I/II ${ }^{-/-}$tracheal grafts $(17,52,53)$. Likewise, although $\mathrm{H} 2-\mathrm{DM} \alpha^{-1-}$ mice express predominantly surface self CLIP-bound (and not allopeptide-bound) MHC II molecules, not all cell surface MHC II molecules are bound to CLIP (32, 54). However, the significance of non-CLIP-bound MHC II in graft rejection is not clear (18). In addition, the mechanism of H2-DM-dependent peptide loading is allele specific. The exchange of CLIP for allopeptides in $\mathrm{H} 2-\mathrm{A}^{\mathrm{b}}$ mice that we employed is highly dependent on $\mathrm{H} 2-\mathrm{DM}$ expression in comparison to any other mouse strains (e.g., H2- $\mathrm{A}^{\mathrm{k}}, \mathrm{H} 2-\mathrm{A}^{\mathrm{d}}$ ) (21-23). Third, because the pretransplant and post-transplant graft-specific microenvironment may account for the different contributions of allorecognition pathways among organ transplants and models, the result in this lung transplant model may not be applicable to others and requires further investigation. Finally, the effect of immunosuppressants used in clinical transplant, which may have different influences on direct and indirect alloreacitivity, was not tested here. We are making plans to include immunosuppressants in future experiments.

In conclusion, this comprehensive study of alloantigen recognition in the mouse heterotopic tracheal transplant model demonstrated a hierarchical order of allorecognition pathways for initiating chronic airway rejection. Although the indirect allorecognition pathway is more important, the significance of both allorecognition pathways should be taken into consideration when developing strategies to protect recipients from allograft rejection. This is the first study that takes advantage of H2$\mathrm{DM} \alpha^{-1-}$ mice to demonstrate the importance of the allopeptide loading process in indirect recognition in lung transplant rejection. In addition, we demonstrated that MHC class I molecules are the principle alloantigens triggering rejection in the mouse model of OB, whereas MHC II and minor antigens are likely to play a less important role. Further studies in other models, as well as in the clinical arena, are essential to confirm these findings. Studies to assess the donor-directed specificities of airway graft-infiltrating lymphocytes are also necessary and are under current investigation.

Acknowledgment: The authors thank Steven B. Wagoner for his professional graphical assistance and continued support, Tracy L. Eldred and Kim A. Burns for their exceptional and long-term assistance in histologic studies, and the investigators and staff at the Cystic Fibrosis Research and Treatment Center, University of North Carolina at Chapel Hill.

\section{References}

1. Hosenpud JD, Bennett LE, Keck BM, Boucek MM, Novick RJ. The Registry of the International Society for Heart and Lung Transplantation: eighteenth official report-2001. J Heart Lung Transplant 2001;20: $805-815$.

2. Hertz MI, Jessurun J, King MB, Savik SK, Murray JJ. Reproduction of the obliterative bronchiolitis lesion after heterotopic transplantation of mouse airways. Am J Pathol 1993;142:1945-1951.

3. Kelly KE, Hertz MI, Mueller DL. T-cell and major histocompatibility complex requirements for obliterative airway disease in heterotopically transplanted murine tracheas. Transplantation 1998;66:764-771.

4. Neuringer IP, Mannon RB, Coffman TM, Parsons M, Burns K, Yankaskas JR, Aris RM. Immune cells in a mouse airway model of obliterative bronchiolitis. Am J Respir Cell Mol Biol 1998;19:379-386.

5. Neuringer IP, Walsh SP, Mannon RB, Gabriel S, Aris RM. Enhanced T cell cytokine gene expression in mouse airway obliterative bronchiolitis. Transplantation 2000;69:399-405.

6. Neuringer IP, Aris RM, Burns KA, Bartolotta TL, Chalermskulrat W, Randall SH. Epithelial kinetics in mouse heterotopic tracheal allografts. Am J Transplant 2002;2:410-419.

7. Rumbley CA, Silver SJ, Phillips SM. Dependence of murine obstructive airway disease on CD40 ligand. Transplantation 2001;72:1616-1625. 
8. Aris RM, Walsh S, Chalermskulrat W, Hathwar V, Neuringer IP. Growth factor upregulation during obliterative bronchiolitis in the mouse model. Am J Respir Crit Care Med 2002;166:417-422.

9. Rogers N, Lechler R. Allorecognition. Am J Transplant 2001;1:97.

10. Shoskes DA, Wood KJ. Indirect presentation of MHC antigens in transplantation. Immunol Today 1994;15:32-38.

11. Auchincloss H Jr, Sultan H. Antigen processing and presentation in transplantation. Curr Opin Immunol 1996;8:681-687.

12. Benichou G. Direct and indirect antigen recognition: the pathways to allograft immune rejection. Front Biosci 1999;4:D476-D480.

13. Sherman LA, Chattopadhyay S. The molecular basis of allorecognition. Annu Rev Immunol 1993:11:385-402.

14. Grusby MJ, Johnson RS, Papaioannou VE, Glimcher LH. Depletion of CD4+ T cells in major histocompatibility complex class II-deficient mice. Science 1991;253:1417-1420.

15. Cosgrove D, Gray D, Dierich A, Kaufman J, Lemeur M, Benoist C, Mathis D. Mice lacking MHC class II molecules. Cell 1991;66:10511066

16. Koller BH, Smithies O. Inactivating the beta 2-microglobulin locus in mouse embryonic stem cells by homologous recombination. Proc Natl Acad Sci USA 1989;86:8932-8935.

17. Zijlstra M, Bix M, Simister NE, Loring JM, Raulet DH, Jaenisch R. Beta 2-microglobulin deficient mice lack CD4-8+ cytolytic T cells. Nature 1990;344:742-746.

18. Felix NJ, Brickey WJ, Griffiths R, Zhang J, Van Kaer L, Coffman T, Ting JP. H2-DMalpha(-/-) mice show the importance of major histocompatibility complex-bound peptide in cardiac allograft rejection. $J$ Exp Med 2000;192:31-40.

19. Fung-Leung WP, Surh CD, Liljedahl M, Pang J, Leturcq D, Peterson PA, Webb SR, Karlsson L. Antigen presentation and T cell development in H2-M-deficient mice. Science 1996;271:1278-1281.

20. Miyazaki T, Wolf P, Tourne S, Waltzinger C, Dierich A, Barois N, Ploegh $\mathrm{H}$, Benoist C, Mathis D. Mice lacking H2-M complexes, enigmatic elements of the MHC class II peptide-loading pathway. Cell 1996;84: 531-541.

21. Martin WD, Hicks GG, Mendiratta SK, Leva HI, Ruley HE, Van Kaer L. H2-M mutant mice are defective in the peptide loading of class II molecules, antigen presentation, and $\mathrm{T}$ cell repertoire selection. Cell 1996;84:543-550.

22. Wolf PR, Tourne S, Miyazaki T, Benoist C, Mathis D, Ploegh HL. The phenotype of H-2M-deficient mice is dependent on the MHC class II molecules expressed. Eur J Immunol 1998;28:2605-2618.

23. Stebbins CC, Loss GE Jr, Elias CG, Chervonsky A, Sant AJ. The requirement for DM in class II-restricted antigen presentation and SDSstable dimer formation is allele and species dependent. $J$ Exp Med 1995;181:223-234.

24. Auchincloss H Jr, Lee R, Shea S, Markowitz JS, Grusby MJ, Glimcher LH. The role of "indirect" recognition in initiating rejection of skin grafts from major histocompatibility complex class II-deficient mice. Proc Natl Acad Sci USA 1993;90:3373-3377.

25. Benichou G, Takizawa PA, Olson CA, McMillan M, Sercarz EE. Donor major histocompatibility complex (MHC) peptides are presented by recipient MHC molecules during graft rejection. J Exp Med 1992;175: 305-308.

26. Jones ND, Van Maurik A, Hara M, Spriewald BM, Witzke O, Morris PJ, Wood KJ. CD40-CD40 ligand-independent activation of CD8+ T cells can trigger allograft rejection. J Immunol 2000;165:1111-1118.

27. Kreisel D, Krupnick AS, Gelman AE, Engels FH, Popma SH, Krasinskas AM, Balsara KR, Szeto WY, Turka LA, Rosengard BR. Non-hematopoietic allograft cells directly activate $\mathrm{CD} 8+\mathrm{T}$ cells and trigger acute rejection: an alternative mechanism of allorecognition. Nat Med 2002; 8:233-239.

28. Boisgerault F, Liu Y, Anosova N, Ehrlich E, Dana MR, Benichou G Role of cd4(+) and cd8(+) T cells in allorecognition: lessons from corneal transplantation. J Immunol 2001;167:1891-1899.

29. Grusby MJ, Auchincloss H Jr, Lee R, Johnson RS, Spencer JP, Zijlstra M, Jaenisch R, Papaioannou VE, Glimcher LH. Mice lacking major histocompatibility complex class I and class II molecules. Proc Natl Acad Sci USA 1993;90:3913-3917.

30. Benichou G, Valujskikh A, Heeger PS. Contributions of direct and indirect $\mathrm{T}$ cell alloreactivity during allograft rejection in mice. J Immunol 1999:162:352-358.

31. Surh CD, Lee DS, Fung-Leung WP, Karlsson L, Sprent J. Thymic selection by a single $\mathrm{MHC} /$ peptide ligand produces a semidiverse repertoire of CD4+ T cells. Immunity 1997;7:209-219.
32. Tourne S, Miyazaki T, Oxenius A, Klein L, Fehr T, Kyewski B, Benoist C, Mathis D. Selection of a broad repertoire of CD4+ T cells in $\mathrm{H}-$ 2Ma0/0 mice. Immunity 1997;7:187-195.

33. Ardehali A, Fischbein MP, Yun J, Irie Y, Fishbein MC, Laks H. Indirect alloreactivity and chronic rejection. Transplantation 2002;73:18051807.

34. SivaSai KS, Smith MA, Poindexter NJ, Sundaresan SR, Trulock EP, Lynch JP, Cooper JD, Patterson GA, Mohanakumar T. Indirect recognition of donor HLA class I peptides in lung transplant recipients with bronchiolitis obliterans syndrome. Transplantation 1999;67:1094-1098.

35. Leonard CT, Soccal PM, Singer L, Berry GJ, Theodore J, Holt PG, Doyle RL, Rosen GD. Dendritic cells and macrophages in lung allografts: a role in chronic rejection? Am J Respir Crit Care Med 2000;161:1349_ 1354.

36. Reznik SI, Jaramillo A, Sivasai KSR, Womer KL, Sayegh MH, Trulock EP, Alexander PG, Mohanakumar T. Indirect allorecognition of mismatched donor HLA class II peptides in lung transplant recipients with bronchiolitis obliterans syndrome. Am J Transplant 2001;1:228-235.

37. Duncan SR, Leonard C, Theodore J, Lega M, Girgis RE, Rosen GD, Theofilopoulos AN. Oligoclonal CD4(+) T cell expansions in lung transplant recipients with obliterative bronchiolitis. Am J Respir Crit Care Med 2002;165:1439-1444.

38. Fangmann J, Dalchau R, Fabre JW. Rejection of skin allografts by indirect allorecognition of donor class I major histocompatibility complex peptides. $J$ Exp Med 1992;175:1521-1529.

39. Watschinger B, Gallon L, Carpenter CB, Sayegh MH. Mechanisms of allo-recognition: recognition by in vivo-primed $\mathrm{T}$ cells of specific major histocompatibility complex polymorphisms presented as peptides by responder antigen-presenting cells. Transplantation 1994:57:572-576.

40. Gallon L, Watschinger B, Murphy B, Akalin E, Sayegh MH, Carpenter CB. The indirect pathway of allorecognition: the occurrence of selfrestricted $\mathrm{T}$ cell recognition of allo-MHC peptides early in acute renal allograft rejection and its inhibition by conventional immunosuppression. Transplantation 1995;59:612-616.

41. Vella JP, Spadafora-Ferreira M, Murphy B, Alexander SI, Harmon W, Carpenter CB, Sayegh MH. Indirect allorecognition of major histocompatibility complex allopeptides in human renal transplant recipients with chronic graft dysfunction. Transplantation 1997;64:795-800

42. Hornick PI, Mason PD, Yacoub MH, Rose ML, Batchelor R, Lechler RI. Assessment of the contribution that direct allorecognition makes to the progression of chronic cardiac transplant rejection in humans Circulation 1998;97:1257-1263.

43. Szeto WY, Krasinskas AM, Kreisel D, Popma SH, Rosengard BR. Donor antigen-presenting cells are important in the development of obliterative airway disease. J Thorac Cardiovasc Surg 2000;120:1070-1077.

44. Smith MA, Jaramillo A, SivaSai KS, Naziruddin B, Kaleem Z, Patterson GA, Mohanakumar T. Indirect recognition and antibody production against a single mismatched HLA-A2-transgenic molecule precede the development of obliterative airway disease in murine heterotopic tracheal allografts. Transplantation 2002;73:186-193.

45. Markmann JF, Bassiri H, Desai NM, Odorico JS, Kim JI, Koller BH, Smithies O, Barker CF. Indefinite survival of MHC class I-deficient murine pancreatic islet allografts. Transplantation 1992;54:1085-1089.

46. Osorio RW, Ascher NL, Jaenisch R, Freise CE, Roberts JP, Stock PG Major histocompatibility complex class I deficiency prolongs islet allograft survival. Diabetes 1993;42:1520-1527.

47. Campos L, Naji A, Deli BC, Kern JH, Kim JI, Barker CF, Markmann JF. Survival of MHC-deficient mouse heterotopic cardiac allografts. Transplantation 1995;59:187-191.

48. Kroshus TJ, Kshettry VR, Savik K, John R, Hertz MI, Bolman RM III. Risk factors for the development of bronchiolitis obliterans syndrome after lung transplantation. J Thorac Cardiovasc Surg 1997;114:195-202.

49. Sundaresan S, Mohanakumar T, Smith MA, Trulock EP, Lynch J, Phelan D, Cooper JD, Patterson GA. HLA-A locus mismatches and development of antibodies to HLA after lung transplantation correlate with the development of bronchiolitis obliterans syndrome. Transplantation 1998:65:648-653.

50. Schulman LL, Weinberg AD, McGregor CC, Suciu-Foca NM, Itescu S. Influence of donor and recipient HLA locus mismatching on development of obliterative bronchiolitis after lung transplantation. Am J Respir Crit Care Med 2001;163:437-442.

51. Chalermskulrat W, Neuringer IP, Schmitz JL, Catellier DJ, Gurka MJ, Randell SH, Aris RM. HLA Mismatches Predispose to the Severity of Bronchiolitis Obliterans Syndrome after Lung Transplantation. Chest (In press)

52. Bix M, Raulet D. Functionally conformed free class I heavy chains exist 
on the surface of beta 2 microglobulin negative cells. $J$ Exp Med 1992;176:829-834.

53. Lee RS, Grusby MJ, Laufer TM, Colvin R, Glimcher LH, Auchincloss $\mathrm{H}$ Jr. CD8+ effector cells responding to residual class I antigens, with help from CD4+ cells stimulated indirectly, cause rejection of "major histocompatibility complex-deficient" skin grafts. Transplantation 1997; 63:1123-1133.

54. Grubin CE, Kovats S, deRoos P, Rudensky AY. Deficient positive selec- tion of CD4 T cells in mice displaying altered repertoires of MHC class II-bound self-peptides. Immunity 1997;7:197-208.

55. Neuringer IP, Chalermskulrat W, Mannon RB, Bartolotta TL, Burns KA, Randell SH, Aris RM. Suppress donor MHC I expression inhibits mouse tracheal graft obliteration. Am J Respir Crit Care Med 2000; 161:A370.

56. Chalermskulrat W, Neuringer IP, Ting JP, Felix NJ, Randell SH, Hathwar VK, Aris RM. Alloantigen recognition in the mouse heterotopic model of OB. Am J Respir Crit Care Med 2002;165:A402. 